\title{
In vitro analysis of the role of the mitochondrial apoptosis pathway in CSBE therapy against human gastric cancer
}

\author{
YU-BIN JI ${ }^{1-3}$ and LEI YU ${ }^{1-3}$ \\ ${ }^{1}$ Center of Research and Development on Life Sciences and Environmental Sciences, Harbin University of Commerce; \\ ${ }^{2}$ Institute of Materia Medica and Postdoctoral Programme of Harbin University of Commerce; \\ ${ }^{3}$ Engineering Research Center of Natural Anticancer Drugs, Ministry of Education, Harbin, Heilongjiang 150076, P.R. China
}

Received November 28, 2014; Accepted August 21, 2015

DOI: $10.3892 /$ etm.2015.2779

\begin{abstract}
The caper plant (Capparis spinosa L.) was a common Uyghur folk medicine, and is a member of the Capparidaceae family. In a previous study, the n-butanol extract of $C$. spinosa L. (CSBE) was demonstrated to exert anti-tumor activity; however, the underlying mechanism is currently not understood. The present study aimed to elucidate the mechanism underlying the CSBE-induced mitochondrial apoptotic pathway, in order to investigate the anti-tumor effects of this plant extract. CSBE-induced apoptosis of the SGC-7901 human gastric cancer cell line was observed, and alterations in the expression levels and localization of initiators, markers, and executors of the mitochondrial apoptosis pathway were analyzed. Following treatment of SGC-7901 cells with CBSE, proliferation was inhibited and apoptosis was induced; and these effects were associated with mitochondrial membrane potential disruption, cytochrome $c$ release into the cytoplasm, and caspase-9 and caspase-3 activation. CSBE may have induced SGC-7901 cell apoptosis by upregulating the expression of B-cell lymphoma-2 (BCL-2)-associated X protein, and downregulating the expression of BCL-2. The results of the present study suggested that CSBE may induce SGC-7901 cell apoptosis via activation of the mitochondrial apoptosis pathway.
\end{abstract}

\section{Introduction}

Capparis spinosa L. is a common Uyghur folk medicine and is a member of the Capparidaceae family, which is used in phytomedicine worldwide for its reported anti-oxidative (1-4), anti-fungal (5), anti-bacterial (6), anti-hepatotoxic (7),

Correspondence to: Dr Lei Yu, Center of Research and Development on Life Sciences and Environmental Sciences, Harbin University of Commerce, 138 Tongda Street, Harbin, Heilongjiang 150076, P.R. China

E-mail: yulei912@163.com

Key words: Capparis spinosa L., n-butanol extract, anti-tumor, mitochondrial apoptosis, SGC-7901 cells anti-inflammatory $(8,9)$, anti-diabetic (10-12), anti-proliferative (13) and anti-tumor (14) effects.

Gastric cancer is the fifth most prevalent type of cancer and the third leading cause of cancer-associated mortality worldwide (15). In 2012, 950,000 cases of gastic cancer were diagnosed, and $~ 723,000$ cases of gastric cancer-related mortality were recorded. Typical treatments for gastric cancer include surgical tumor excision, chemotherapy, radiotherapy and targeted therapy (16). Various combinations of drugs may be used in the treatment of gastric cancer, including flurouracil, capecitabine, carmustine, semustine and doxorubicin, in addition to mitomycin C, cisplatin and docetaxel. However, gastric cancer frequently exhibits low sensitivity to these treatments, which are typically used to palliatively reduce the tumor size, relieve symptoms and increase survival time. Therefore, there is a requirement for novel treatment options for the treatment and prevention of gastric cancer.

A preliminary study indicated that in vitro anti-tumor activity exerted by the n-butanol extract of $C$. spinosa $\mathrm{L}$. (CSBE) (17); however, the underlying molecular mechanism of CSBE-induced tumor cell apoptosis is currently poorly understood. The present study aimed to elucidate the mechanisms underlying CSBE-induced apoptosis of the SGC-7901 human gastric cancer cell line by investigating alterations to the expression levels and localization of initiators, effectors, and markers of the mitochondrial apoptosis pathway, following CSBE exposure.

\section{Materials and methods}

Materials. CSBE was provided by the Institute of Materia Medica at the Harbin University of Commerce (Harbin, China). The MTT cell proliferation assay, propidium iodide (PI), and Rhodamine 123 dye were purchased from Sigma-Aldrich (St. Louis, MO, USA). RPMI-1640 medium was purchased from Gibco Life Technologies (Carlsbad, CA, USA) and fetal calf serum (FCS) was purchased from GE Healthcare Life Sciences (Logan, UT, USA). Caspase-9 and caspase-3 test kits were purchased from Biyuntian Co. (Shanghai, China). TRIzol ${ }^{\circledR}$ reagent was purchased from Invitrogen Life Technologies (Carlsbad, CA, USA), and monoclonal antibodies against $\beta$-actin (sc-47778), cytochrome $c$, B-cell lymphoma-2 (BCL-2; sc-7382) and BCL-2-associated protein X (BAX; 

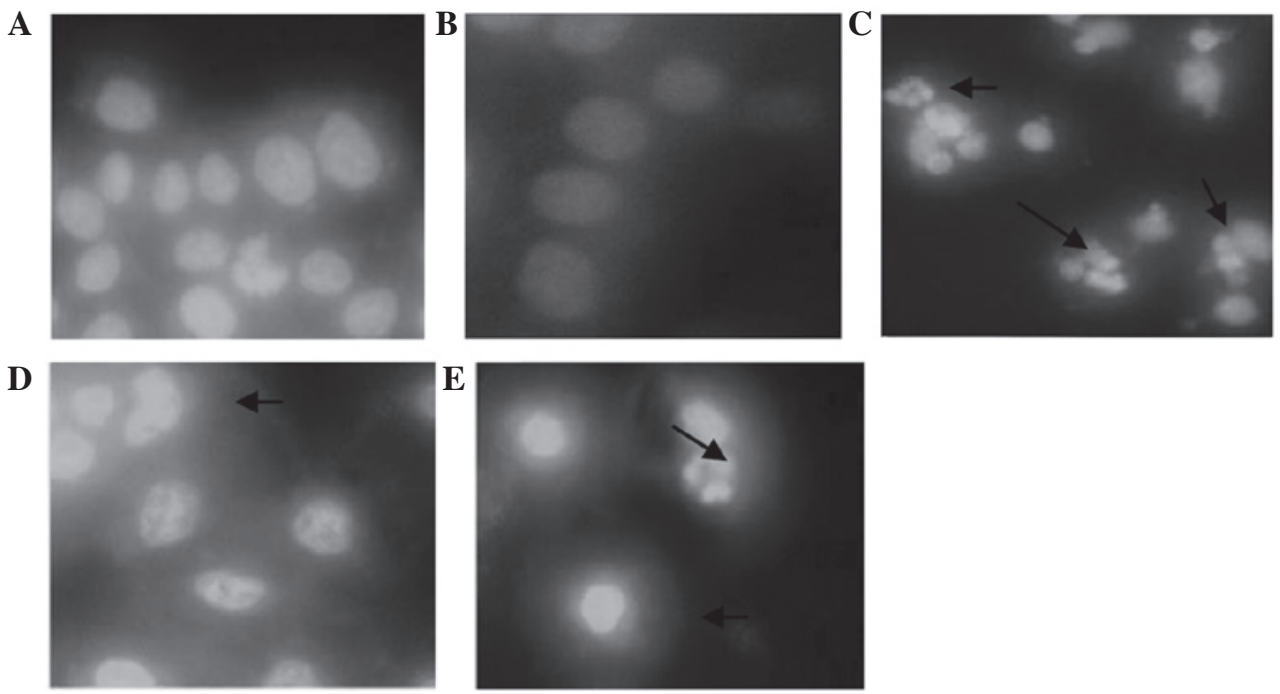

Figure 1. Effects of the n-butanol extract of Capparis spinosa L. (CSBE) on the morphology of SGC-7901 human gastric cancer cells. In all groups, cells were stained with Hoechst 33258 and observed by fluorescence microscopy (magnification, $\mathrm{x} 400)$ : (A) Control; (B) hydroxycamptothecin treatment (0.2 $\mu \mathrm{g} / \mathrm{ml})$ at $24 \mathrm{~h}$; (C) CSBE treatment $(15 \mu \mathrm{g} / \mathrm{ml})$ at $24 \mathrm{~h}$; (D) CSBE treatment $(30 \mu \mathrm{g} / \mathrm{ml})$ at $24 \mathrm{~h}$; and (E) CSBE treatment (60 $\mu \mathrm{g} / \mathrm{ml})$ at $24 \mathrm{~h}$. Examples of apoptotic cells, exhibiting condensed, crescentic or "popcorn" nuclear morphology, are highlighted with black arrows.

sc-7480) were purchased from Santa Cruz Biotechnology, Inc. (Dallas, TX, USA). Horse anti-mouse alkaline phosphatase (AP)-conjugated (ZB-2310) and goat anti-mouse fluorescein-conjugated antibodies (ZF-0312) were purchased (ZSBio; OriGene Technologies, Inc., Beijing, China).

Cell culture. The SGC-7901 human gastric carcinoma cell line (Institute of Materia Medica, Chinese Academy of Medical Sciences, Peking, China) was cultured in RPMI-1640 medium supplemented with $10 \% \mathrm{FCS}$ at $37^{\circ} \mathrm{C}$, in a $5 \% \mathrm{CO}_{2}$ incubator.

MTT proliferation assay. The MTT assay is a colorimetric assay for assessing cell viability (18). Logarithmic phase cells $\left(2 \times 10^{5} / \mathrm{ml}\right)$ were grown in 96 -well plates. Following $24 \mathrm{~h}$ of growth, various concentrations of $100 \mu \mathrm{l} \mathrm{CSBE}$, fresh medium and hydroxycamptothecin (HCPT; 20090430; Harbin Pharmaceutical Group Co., Ltd.), were added to each well. HCPT has apparent anti-tumor activities and is an alkaloid, while CSBE also has an alkaloid component. So HCPT was used for positive control. Six parallel wells were set up for each group: $\operatorname{CSBE}(1,5,25,50,75$ and $100 \mu \mathrm{g} / \mathrm{ml})$; HCPT (0.01, 0.1, 1 and $10 \mu \mathrm{g} / \mathrm{ml}$ ); and control (RPMI-1640). After $72 \mathrm{~h}$, cell viability was assayed via the addition of $0.5 \mathrm{mg} / \mathrm{ml}$ MTT dye. After $4 \mathrm{~h}$ incubation at $37^{\circ} \mathrm{C}$, the medium was removed, formazan crystals were dissolved in $200 \mu$ l dimethyl sulfoxide/well, and the 96-well plates were read in a microplate reader (Wellscan MK3; Bio-Rad Laboratories, Inc., Hercules, CA, USA) at $570 \mathrm{~nm}$. The rate of inhibition of CSBE on SGC-7901 cell proliferation was calculated as follows: Inhibition rate $=$ (optical density (OD) of control group - OD of CSBE group) x (100\%/OD of control group).

Apoptotic morphology assay. SGC-7901 cells were inoculated into 6 -well plates $\left(3 \times 10^{8}\right.$ cells $\left./ \mathrm{ml}\right)$, in which each well contained a coverslip. At $24 \mathrm{~h}, \operatorname{CSBE}(15,30$ or $60 \mu \mathrm{g} / \mathrm{ml})$ was added to each well. The final concentration of HCPT (positive control group) was $0.2 \mu \mathrm{g} / \mathrm{ml}$, whereas the negative control group received the same volume of culture medium. After $40 \mathrm{~h}$ the supernatant was discarded, and the SGC-7901 cells were washed in phosphate-buffered saline (PBS), and fixed in buffered solution (volume ratio of methyl alcohol:glacial acetic acid was $3: 1$ ) at $4^{\circ} \mathrm{C}$ for $10 \mathrm{~min}$. Subsequently, $5 \mathrm{mg} / \mathrm{l}$ of Hoechst 33258 (861405; Sigma-Aldrich), the fluorescent probe, was added into each well. Following $30 \mathrm{~min}$ in the dark at $37^{\circ} \mathrm{C}$, the cells were washed in PBS and the coverslip in each well was removed under a $\mathrm{CKX}-41$ fluorescence microscope, and the stained cells were visualized using a digital camera (both from Olympus Corporation, Tokyo, Japan).

Apoptotic rate assay. PI single-staining of SGC-7901 cells was performed according to a method outlined in previous studies (19,20). Briefly, SGC-7901 cells were plated into a 6-well plate $\left(3 \times 10^{5}\right.$ cells $\left./ \mathrm{ml}\right)$ and $\operatorname{CSBE}(15,30$ or $60 \mu \mathrm{g} / \mathrm{ml})$ was added at $24 \mathrm{~h}$. After $48 \mathrm{~h}$, the cells were collected and fixed in $70 \%$ ethanol and stored at $4{ }^{\circ} \mathrm{C}$ overnight. Following removal of the ethanol, the SGC-7901 cells were suspended in PI dye $(50 \mu \mathrm{g} / \mathrm{ml})$ at $37^{\circ} \mathrm{C}$ for $30 \mathrm{~min}$. Subsequently, the cells were analyzed using flow cytometry (EPICS XL-MCL; Beckman Coulter, Inc., Brea, CA, USA), in which the excitation wavelength was $488 \mathrm{~nm}$ and the emission wavelength was $630 \mathrm{~nm}$.

Measurement of mitochondrial membrane potential. The SGC-7901 cells were inoculated into a 6-well plate ( $2 \times 10^{5}$ cells $\left./ \mathrm{ml}\right)$, after which CSBE $(15,30$ or $60 \mu \mathrm{g} / \mathrm{ml})$ was added after $24 \mathrm{~h}$. The cells were collected at $48 \mathrm{~h}$ and suspended in Rhodamine 123 dye $(10 \mu \mathrm{g} / \mathrm{ml})$ for $30 \mathrm{~min}$. Subsequently, the cells were centrifuged $(340 \mathrm{x} \mathrm{g}, 10 \mathrm{~min})$ and washed with PBS. Fluorescence intensity was measured via flow cytometry, in which the excitation wavelength was $488 \mathrm{~nm}$ and the emission wavelength was $525 \mathrm{~nm}$.

Measurement of caspase-9 and caspase-3 activity. The SGC-7901 cells were inoculated into a 6-well plate 

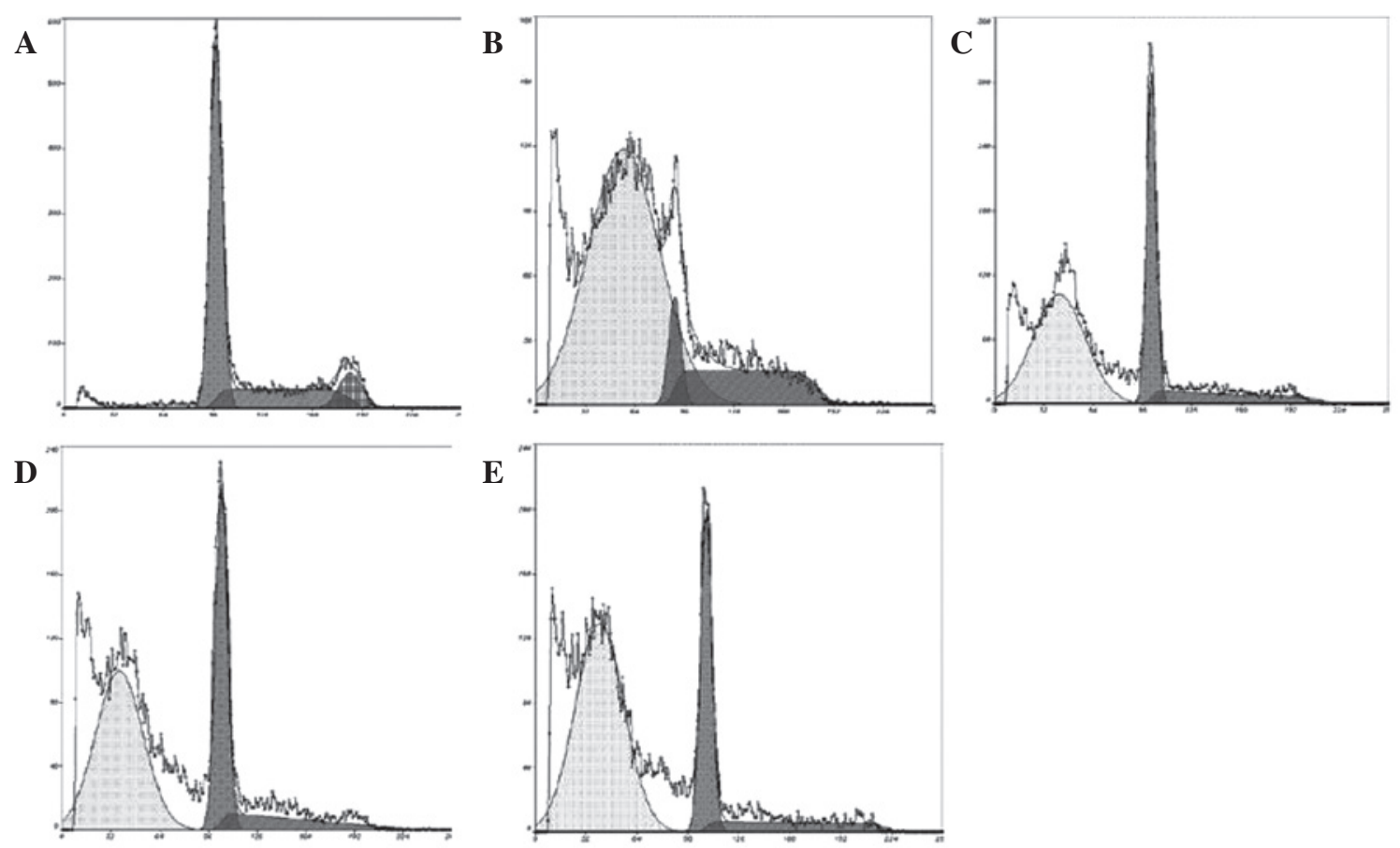

Figure 2. Proportion of SGC-7901 apoptotic cells following inoculation with the n-butanol extract of Capparis spinosa L. (CSBE). DNA content data from flow cytometry of SGC-7901 cells cultured with or without CSBE for $48 \mathrm{~h}$, as assayed by propidium iodide incorporation. (A) Control; (B) hydroxycamptothecin treatment $(0.2 \mu \mathrm{g} / \mathrm{ml})$; (C) CSBE treatment $(15 \mu \mathrm{g} / \mathrm{ml})$; (D) CSBE treatment $(30 \mu \mathrm{g} / \mathrm{ml})$; and (E) CSBE treatment $(60 \mu \mathrm{g} / \mathrm{ml})$, at $24 \mathrm{~h}$. CSBE induced DNA synthesis by $48 \mathrm{~h}$, as is evidenced by the formation of an apoptotic peak (sub- $\mathrm{G}_{0} / \mathrm{G}_{1}$ fraction), corresponding to labeled cells with a decreased DNA content.

( $1 \times 10^{6}$ cells $/ \mathrm{ml}$, cells inoculated into a $100-\mathrm{ml}$ culture bottle) and CSBE $(15,30$ or $60 \mu \mathrm{g} / \mathrm{ml})$ was added at $24 \mathrm{~h}$. Subsequently, the cells were incubated $\left(100 \mu \mathrm{l} / 2 \times 10^{6}\right.$ cells) with Ac-DEVD-pNA lysis buffer (Beyotime Institute of Biotechnology, Shanghai, China) in an ice bath for $15 \mathrm{~min}$, following suspension of the precipitation. Following centrifugation at $4^{\circ} \mathrm{C}$ for $10 \mathrm{~min}$ at $21,000 \times \mathrm{g}$, the culture supernatant was transferred to a cooling centrifuge tube, and $90 \mu \mathrm{l}$ detecting buffer, and $10 \mu \mathrm{l}$ Ac-DEVD-pNA colorimetric substrate $(2 \mathrm{mM})$, were added to the control group. Subsequently, $60 \mu 1$ detecting buffer, $10 \mu 1$ Ac-DEVD-pNA $(2 \mathrm{mM})$ and $10 \mu \mathrm{l}$ sample were added to the sample group. All of the samples were incubated at $37^{\circ} \mathrm{C}$ for $60 \mathrm{~min}$. The Ac-DEVD-pNA (10 mM) was diluted to 0, 10, 20, 50, 100 and $200 \mu \mathrm{mol} / 1$, which were used to generate a standard curve. Absorbance at $405 \mathrm{~nm}$ was determined using an enzyme-labeled instrument (Wellscan MK3), when the color was significantly altered.

Western blot analysis. The SGC-7901 cells were inoculated into a 6 -well plate $\left(1 \times 10^{6}\right.$ cells $/ \mathrm{ml}$, cells were inoculated into a $100-\mathrm{ml}$ culture bottle), and $\operatorname{CSBE}(15,30$ or $60 \mu \mathrm{g} / \mathrm{ml})$ was added following $24 \mathrm{~h}$. Total protein extraction occurred at $48 \mathrm{~h}$, and protein content was measured using Bradford Protein Assays (20100216; Beyotime). After 24 h of administration, cells were washed twice with PBS, then scraped. The lysate was added, and the samples were chilled on ice for $30 \mathrm{~min}$. The cells were centrifugated at $4^{\circ} \mathrm{C}$ for $10 \mathrm{~min}(21,000 \mathrm{x} \mathrm{g})$, while the supernatant fluid was separated from the total protein. Equivalent amounts of protein $(3 \mu \mathrm{g} / \mathrm{ml})$ were separated using $15 \%$ SDS-PAGE. The proteins were transferred to a nitrocellulose membrane (10401196; Whatman; GE Healthcare Life

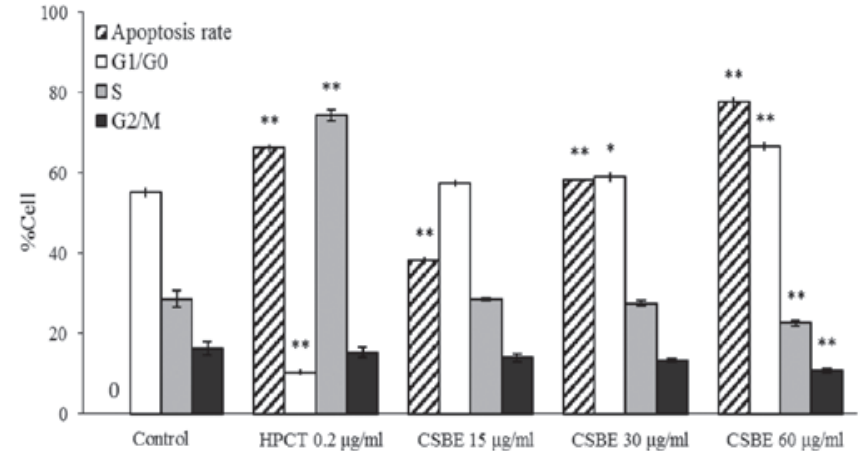

Figure 3. Effect of the n-butanol extract of Capparis spinosa L. (CSBE) on the cell cycle distribution of SGC-7901 cells. Cell percentage of apoptosis as determined by flow cytometry. Cells were treated with hydroxycamptothecin (HCPT; $0.2 \mu \mathrm{g} / \mathrm{ml}$ ) or 15,30 or $60 \mu \mathrm{g} / \mathrm{ml} \mathrm{CSBE}$ for $48 \mathrm{~h}$. Subsequently, the cells were stained with propidium iodide and analyzed using flow cytometry. ${ }^{*} \mathrm{P}<0.05$, as compared with the control; ${ }^{* *} \mathrm{P}<0.01$, compared with the control.

Sciences, Shanghai, China), which was blocked using 5\% skimmed milk, washed using Tris-buffered saline containing Tween 20 (TBST) and stored at $4^{\circ} \mathrm{C}$ for $2 \mathrm{~h}$. Subsequently, the nitrocellulose membrane was incubated with anti-BCL-2, anti-BAX, anti-cytocrome $c$ and anti- $\beta$-actin polyclonal antibodies (1:200) overnight at $4^{\circ} \mathrm{C}$. Following washing with TBST, the nitrocellulose membrane was incubated with AP-conjugated secondary antibodies (1:500) at room temperature for $2 \mathrm{~h}$, after which the membrane was incubated with the AP-NBT/BCIP substrate solution (ZLI-9041; ZSBio; OriGene Technologies, Inc.). Bound antibodies were detected using the Tanon Gel Imaging system (GIS-2019; Tanon Science \& 

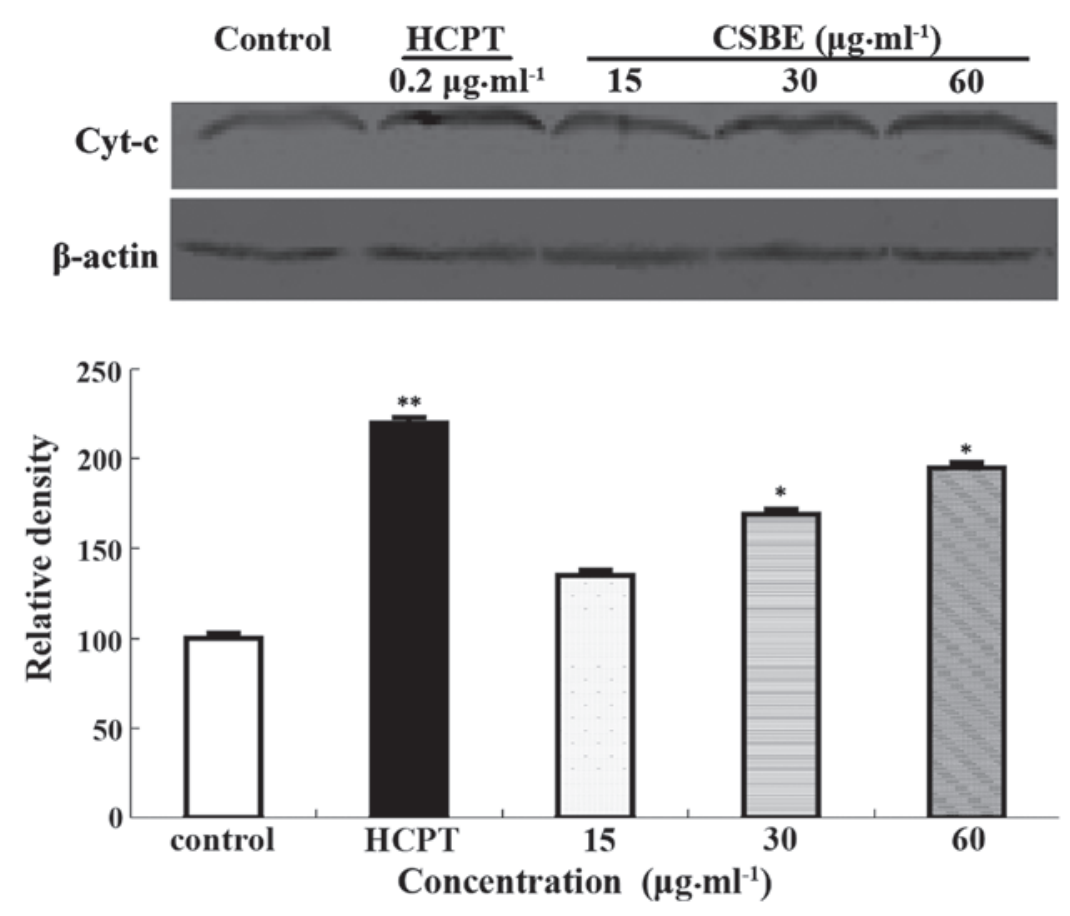

Figure 4. Effect of the n-butanol extract of Capparis spinosa L. (CSBE) on cytochrome $c$ (Cyt-c) release. Levels of Cyt-c in the mitochondrial pellet were measured following $24 \mathrm{~h}$ incubation with or without CSBE $(15,30$ or $60 \mu \mathrm{g} / \mathrm{ml})$ or hydroxycamptothecin (HCPT) by western blotting. The levels of cytochrome $c$ in the cytoplasm following CSBE exposure increased in a dose-dependent manner. Each blot represents the results of three similar experiments. ${ }^{*}<0.05$, as compared with the control; ${ }^{* *} \mathrm{P}<0.01$, as compared with the control.

Technology Co., Ltd., Shanghai, China), and were analyzed quantitatively using the Gel-Pro Analyzer 3.1 Density Analysis software (Media Cybernetics, Inc., Rockville, MD, USA).

Isolation of total RNA from SGC-7901 cells and reverse transcription-polymerase chain reaction (RT-PCR). SGC-7901 cells were inoculated into a 6 -well plate $\left(1 \times 10^{6}\right.$ cells $/ \mathrm{ml}$, cells inoculated into a 75-ml culture bottle), after which CSBE (15, 30 or $60 \mu \mathrm{g} / \mathrm{ml}$ ) was added at $24 \mathrm{~h}$. Total RNA was extracted using TRIzol ${ }^{\circledR}$ reagent after $24 \mathrm{~h}$. Qualitative analysis of the total RNA was performed using gel electrophoresis to evaluate the purity and degradation of the RNA. The RT reaction was performed in accordance with the manufacturer's instructions (Takara Biotechnology Co., Ltd., Dalian, China). Primers were synthesized by Sangon Biotech Co., Ltd.(Shanghai, China). The primer sequences were as follows: BCL-2 (458 bp), forward 5'-GGTGCCACCTGTGGTCCACCT-3', reverse 5'-CTTCACTTGTGGCCCAGATAGG-3'; BAX (382 bp), forward 5'-CGTCCACCAAGAAGCTGAGCG-3', reverse 5'-AGCACTCCCGCCACAAAGATG-3'; $\beta$-actin (540 bp), forward 5'-GTGGGGCGCCCCAGGCACCA-3', reverse 5'-CTTCCTTAATGTCACGCACGATTTC-3'. The reaction conditions of the PCR were: $94^{\circ} \mathrm{C}$ for $3 \mathrm{~min} ; 94^{\circ} \mathrm{C}$ for $30 \mathrm{sec}$; $72^{\circ} \mathrm{C}$ for $1 \mathrm{~min}$; and $72^{\circ} \mathrm{C}$ for $8 \mathrm{~min}$. BCL-2 underwent 32 cycles and BAX underwent 30 cycles. $\beta$-actin underwent $94^{\circ} \mathrm{C}$ for $2 \mathrm{~min}, 94^{\circ} \mathrm{C}$ for $30 \mathrm{sec}, 58^{\circ} \mathrm{C}$ for $30 \mathrm{sec}$, and $72^{\circ} \mathrm{C}$ for $60 \mathrm{sec}$. The products of the PCR were detected by $2 \%$ sepharose gel electrophoresis, and quantitative analysis of data was performed using the Tanon gel imaging system.

Statistical analysis. PASW Statistics, version 18 (SPSS, Inc., Chicago, IL, USA) was used to analyze the results. Data are

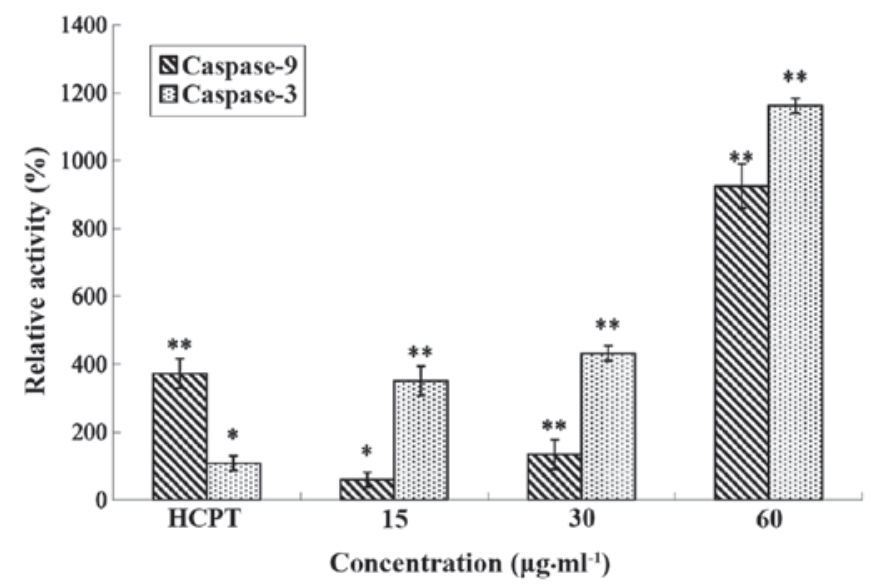

Figure 5. Effect of the n-butanol extract of Capparis spinosa L. (CSBE) on the relative activities of caspase-9/caspase-3 in SGC-7901 human gastric cancer cells. The relative activity of caspase-9/caspase-3 following treatment with $\operatorname{CSBE}(15,30$ or $60 \mu \mathrm{g} / \mathrm{ml})$ increased in a dose-dependent manner. Enzymatic activity is expressed in arbitrary units as optical density/mg protein for each sample. Data are presented as the mean \pm standard deviation of triplicate determinations from 3 experiments. ${ }^{*} \mathrm{P}<0.05$, as compared with the control; ${ }^{* *} \mathrm{P}<0.01$, as compared with control cells (data not shown).

expressed as the mean \pm standard deviation. Differences between groups were examined for statistical significance using one-way analysis of variance. In all cases, $\mathrm{P}<0.05$ was considered to indicate a statistically significant difference.

\section{Results}

Cytotoxic effects of CSBE on SGC-7901 cells. The cytotoxic effects of CSBE on SGC-7901 cells were measured using 




B

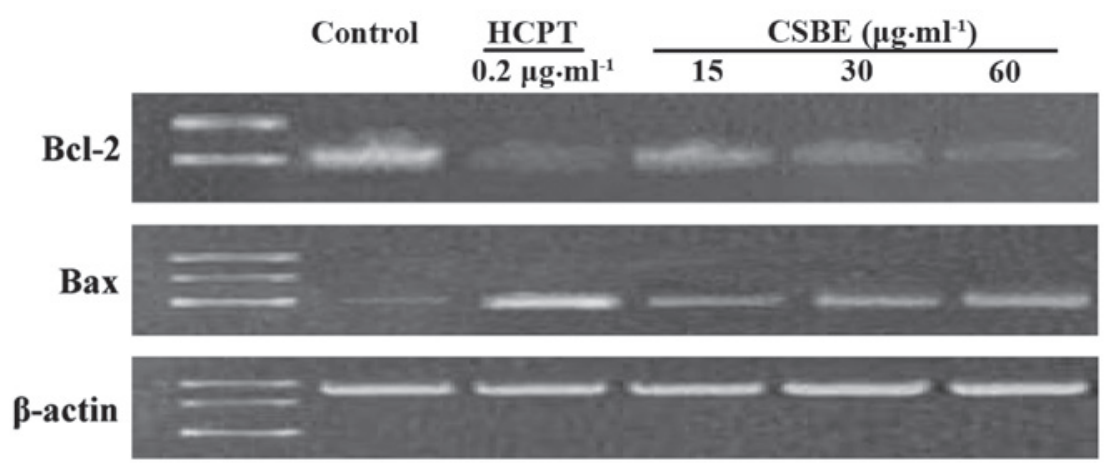

Figure 6. Effect of the n-butanol extract of Capparis spinosa L. (CSBE) on B-cell lymphoma-2 (BCL-2) family proteins in SGC-7901 cells. (A) The expression levels of BCL-2-associated X protein (BAX) and BCL-2 proteins. Following treatment with 15, 30 or $60 \mu \mathrm{g} / \mathrm{ml} \mathrm{CSBE}$, the fractions were resolved by SDS-PAGE, transferred onto nitrocellulose membranes, then probed with specific antibodies and visualized using an alkaline phosphatase-NBT/BICP kit. The levels of $\beta$-actin were measured as an internal control. (B) Reverse transcription-polymerase chain reaction (RT-PCR) analysis of BCL-2 and BAX mRNA levels in CSBE-treated cells. Agarose gel electrophoresis of RT-PCR products of BAX, BCL-2 and GAPDH mRNA isolated from SGC-7901 cells treated with 15,30 or $60 \mu \mathrm{g} / \mathrm{ml} \mathrm{CSBE}$ for $24 \mathrm{~h}$. Each blot represents three similar experiments.

MTT assays. The half maximal inhibitory concentration $\left(\mathrm{IC}_{50}\right)$ of CSBE on SGC-7901 cells was $31.542 \mu \mathrm{g} / \mathrm{ml}$, whereas the $\mathrm{IC}_{50}$ of HCPT was $0.175 \mu \mathrm{g} / \mathrm{ml}$. These results led to the use of the following doses of CSBE in subsequent experiments: 15 , 30 and $60 \mu \mathrm{g} / \mathrm{ml}$.

Effect of CSBE on the morphology of SGC-7901 cells. CSBE administration was associated with significant apoptosis-associated morphological alterations to SGC-7901 cells, as compared with the control group, $24 \mathrm{~h}$ following CSBE treatment. Apoptotic cells were distinguished by the typical nuclear morphology of apoptosis, including profound chromatin condensation, nuclear fragmentation and scattered apoptotic bodies (Fig. 1).

Effect of CSBE on apoptosis and cell cycle distribution of $S G C-7901$ cells. PI-mediated fluorescence-activated cell sorting was used to observe CSBE-induced SGC-7901 cell apoptosis. Following administration of CSBE, the total number of apoptotic SGC-7901 cells significantly increased in a dose-dependent manner (Fig. 2). The proportion of cells undergoing late apoptosis was significantly higher, as compared with the controls. In order to determine whether cell growth inhibition was associated with cell cycle alterations, cell cycle distribution was also determined. CSBE markedly increased the proportion of $\mathrm{G}_{1}$ cells, and reduced the proportion of SGC-7901 cells in the $\mathrm{G}_{2} / \mathrm{M}$ phase, which indicated the occurrence of $\mathrm{G}_{0} / \mathrm{G}_{1}$ phase arrest (Fig. 3).
Table I. Effect of CSBE on the MMP of SGC-7901 cells.

\begin{tabular}{lcc}
\hline Group & $\begin{array}{c}\text { Concentration } \\
(\mu \mathrm{g} / \mathrm{ml})\end{array}$ & $\begin{array}{c}\text { Intracellular MMP } \\
\text { levels }(\%)\end{array}$ \\
\hline Control & 0 & $49.8 \pm 0.18$ \\
CSBE & 15 & $40.7 \pm 0.31^{\mathrm{a}}$ \\
& 30 & $38.8 \pm 0.21^{\mathrm{a}}$ \\
HCPT & 60 & $8.1 \pm 0.12^{\mathrm{a}}$ \\
\hline
\end{tabular}

The percentage indicates the cell population that exhibited positive staining for Rhodamine 123. Data are presented as the mean \pm standard deviation. ${ }^{a} \mathrm{P}<0.01$, as compared with the control. MMP, mitochondrial membrane potential; CSBE, n-butanol extract of Capparis spinosa L.; HCPT, hydroxycamptothecin.

Effect of CSBE on the mitochondrial membrane potential of SGC-7901 cells. The mitochondrial membrane potential decreased in a dose-dependent manner following CSBE exposure, which was indicated by a decrease in the fluorescence intensity (Table I). This was associated with the opening of the mitochondrial permeability transition pore (PTP), which may have resulted in the release of apoptotic factors.

Effect of CSBE on cytochrome c release. Western blotting was used to detect cytochrome $c$ release into the cytoplasm, 
following CSBE exposure. The levels of cytochrome $c$ in the cytoplasm increased in a dose-dependent manner (Fig. 4), which may indicate that cytochrome $c$ is involved in CSBE-induced SGC-7901 apoptosis.

Effect of CSBE on caspase-9 and caspase-3 activity. The relative activity of caspase- $9 /$ caspase-3 was detected using a caspase- 9 and caspase- 3 test kit. Following treatment with CSBE, the relative activity of caspase- $9 /$ caspase- 3 in SGC-7901 cells increased in a dose-dependent manner (Fig. 5).

Effect of CSBE on BCL-2 and BAX protein and $M R N A$ expression levels. Western blotting was used to detect the BCL-2 and BAX protein expression levels in SGC-7901 cells (Fig. 6A). CSBE was able to inhibit BCL-2 protein expression in a dose-dependent manner, with the inhibition rate reaching $56.4 \%$, following exposure to $60 \mu \mathrm{g} / \mathrm{ml} \mathrm{CSBE}$. Conversely, CSBE was demonstrated to increase the levels of BAX protein. RT-PCR was used to detect the effects of CSBE on the transcription of BCL-2 and BAX (Fig. 6B). The results suggest that CSBE may significantly reduce BCL-2 mRNA expression levels and increase BAX mRNA expression levels $24 \mathrm{~h}$ following administration.

\section{Discussion}

CSBE has previously been demonstrated to have dose-dependent, anti-proliferative effects on SGC-7901 cells (21); however, the underlying mechanism remains poorly understood. Previous studies $(22,23)$ evaluated the morphological alterations in SGC-7901 cells undergoing apoptosis using a fluorescence microscope. Furthermore, an analysis of cell cycle distribution in SGC-7901 cells undergoing apoptosis reported that the apoptotic peak, consisting of cells that had lost their DNA content, occurred to the left of the normal genomic peak $\left(G_{1}\right)(24)$. In the present study, exposure of SGC-7901 cells to CSBE was associated with: A dose-dependent accumulation of SGC-7901 cells in the $\mathrm{G}_{0} / \mathrm{G}_{1}$ phase of the cell cycle; morphological changes to the cells; and the presence of an apoptotic peak. The findings of the present study suggested that CSBE may have been able to induce SGC-7901 cell apoptosis.

The mitochondrial membrane potential assay is a sensitive indicator of mitochondrial function in early apoptosis. The mitochondrial membrane potential of SGC-7901 cells markedly decreased following CSBE exposure, and this may have promoted cytochrome $c$ release into the cytoplasm; this in turn may have activated apoptosis via the caspase cascade reaction $(25,26)$. In the present study, CSBE administration in SGC-7901 cells was associated with mitochondrion PTP opening, a decrease in the mitochondrion membrane potential and cytochrome $c$ release into the cytoplasm.

The disruption of the mitochondrial membrane potential is an early event in apoptosis, which may result in activation of apoptotic cascades $(27,28)$. This cascade activation triggers the release of cytochrome $c$, and other apoptotic factors, including second mitochondria-derived activator of caspase/direct inhibitor of apoptosis-binding protein with low $\mathrm{pI}$, into the cytosol. Subsequently, cytochrome $c$ is able to bind apoptotic protease activating factor-1 and activated procaspase-9 (29). Activated caspase- 9 cleaves caspase-3, which is an executioner of apoptosis (30). In the present study, CSBE may have induced the release of cytochrome $c$ into the cytoplasm, which may have subsequently activated caspase- 9 and the downstream caspase-3, leading to SGC-7901 cell apoptosis. Therefore, the results of the present study suggested that CSBE may have indirectly induced SGC-7901 cell apoptosis.

The BCL-2 family consists of pro-apoptotic and anti-apoptotic members, which are associated with the mitochondrial apoptosis pathway. BCL-2 has been demonstrated to preserve mitochondrial integrity, in order to prevent apoptosis, whereas BAX has been demonstrated to promote the release of cytochrome $c$ from the mitochondria, which in turn activates downstream caspases $(31,32)$. In the present study, CSBE was demonstrated to decrease the ratio of BCL-2:BAX, which may have induced SGC-7901 cell apoptosis. The inhibition of BCL-2 protein expression may have prevented BCL-2 and BAX from forming a heterologous dimer, which in turn may have enhanced SGC-7901 cell apoptosis. The results of RT-PCR suggested that CSBE was able to alter the expression levels of BCL-2 and BAX by regulation at the transcriptional level.

In conclusion, CSBE was able to inhibit the proliferation of SGC-7901 cells, induce apoptosis, and initiate $\mathrm{G}_{0} / \mathrm{G}_{1}$ phase arrest. Apoptosis may have been induced via CSBE-mediated upregulation of the pro-apoptotic protein BAX, and downregulation of the anti-apoptotic protein BCL-2, which in turn may have induced a reduction in the mitochondrial membrane potential, leading to mitochondrial cytochrome $c$ release and subsequent activation of caspase-9 and caspase-3. Therefore, CSBE may have induced SGC-7901 cell apoptosis via the mitochondrial apoptosis pathway.

\section{Acknowledgements}

The present study was supported in part by The Open Research Program for Key Laboratory (College of Heilongjiang, China; grant no. CPAT-2012003); The Natural Science Item of Department of Education (Heilongjiang, China; grant no. 12541205); and The Innovation Talents Item of Science and Technology (Harbin, China; grant no. 2014RFQXJ154).

\section{References}

1. Germanò MP, De Pasquale R, D'Angelo V, Catania S, Silvari V and Costa C: Evaluation of extracts and isolated fraction from Capparis spinosa L. buds as an antioxidant source. J Agric Food Chem 50: 1168-1171, 2002.

2. Bonina F, Puglia C, Ventura D, Aquino R, Tortora S, Sacchi A, Saija A, Tomaino A, Pellegrino ML and de Caprariis P: In vitro antioxidant and in vivo phytoprotective effects of a lyophilized extract of Capparis spinosa L buds. Cosmet Sci 53: 321-335, 2002.

3. Siracusa L, Kulisic-Bilusic T, Politeo O, Krause I, Dejanovic B and Ruberto G: Phenolic composition and antioxidant activity of aqueous infusions from Capparis spinosa L. and Crithmum maritimum L. before and after submission to a two-step in vitro digestion model. J Agric Food Chem 59: 12453-12459, 2011.

4. Tlili N, Khaldi A, Triki S and Munné-Bosch S: Phenolic compounds and vitamin antioxidants of caper (Capparis spinosa). Plant Foods Hum Nutr 65: 260-265, 2010.

5. Issac Abraham SV, Palani A, Ramaswamy BR, Shunmugiah KP and Arumugam VR: Antiquorum sensing and antibiofilm potential of Capparis spinosa. Arch Med Res 42: 658-668, 2011.

6. Boga C, Forlani L, Calienni R, Hindley T, Hochkoeppler A Tozzi S and Zanna N: On the antibacterial activity of roots of Capparis spinosa L. Nat Prod Res 25: 417-421, 2011. 
7. Gadgoli C and Mishra SH: Antihepatotoxic activity of p-methoxy benzoic acid from Capparis spinosa. J Ethnopharmacol 66: 187-192, 1999.

8. al-Said MS, Abdelsattar EA, Khalifa SI and el-Feraly FS: Isolation and identification of an anti-inflammatory principle from Capparis spinosa. Pharmazie 43: 640-641, 1988.

9. Zhou HF, Xie C, Jian R, Kang J, Li Y, Zhuang CL, Yang F, Zhang LL, Lai L, Wu T and Wu X: Biflavonoids from Caper (Capparis spinosa L.) fruits and their effects in inhibiting NF-kappa B activation. J Agric Food Chem 59: 3060-3065, 2011.

10. Ziyyat A, Legssyer A, Mekhfi H, Dassouli A, Serhrouchni M and Benjelloun W: Phytotherapy of hypertension and diabetes in oriental Morocco. J Ethnopharmacol 58: 45-54, 1997.

11. Eddouks M, Lemhadri A and Michel JB: Hypolipidemic activity of aqueous extract of Capparis spinosa $\mathrm{L}$. in normal and diabetic rats. J Ethnopharmacol 98: 345-350, 2005.

12. Huseini HF, Hasani-Rnjbar S, Nayebi N, Heshmat R, Sigaroodi FK, Ahvazi M, Alaei BA and Kianbakht S: Capparis spinosa L. (Caper) fruit extract in treatment of type 2 diabetic patients: A randomized double-blind placebo-controlled clinical trial. Complement Ther Med 21: 447-452, 2013.

13. Lam SK and Ng TB: A protein with antiproliferative, antifungal and HIV-1 reverse transcriptase inhibitory activities from caper (Capparis spinosa) seeds. Phytomedicine 16: 444-450, 2009.

14. Bai HJ, Zhou ZB and Zhao XL: Study on activity of anti-H22 of xinjiang province plant Capparis spinosa. Hei Long Jiang Xu Mu Shou Yi 12: 100-101, 2007 (In Chinese).

15. Caldas C, Carneiro F, Lynch HT, Yokota J, Wiesner GL, Powell SM, Lewis FR, Huntsman DG, Pharoah PD Jankowski JA, et al: Familial gastric cancer: Overview and guidelines for management. J Med Genet 12: 873-880, 1999.

16. Dicken JL, van de Velde CJH, Coit DG, Shah MA, Verheij M and Cats A: Treatment of resectable gastric cancer. Therap Adv Gastroenterol 5: 49-69, 2012.

17. Li WL, Yu L and Ji YB: Chemical constituents of n-butanol extract of Capparis spinosa L. Asian J Chem 26: 3435-3437, 2014.

18. Mosmann T: Rapid colorimetric assay for cellular growth and survival: Application to proliferation and cytotoxicity assays. J Immunol Methods 65: 55-63, 1983.

19. Gong J, Traganos F and Darzynkiewicz Z: A selective procedure for DNA extraction from apoptotic cells applicable for gel electrophoresis and flow cytometry. Anal Biochem 218: 314-319, 1994
20. Nicoletti I, Migliorati G, Pagliacci MC, Grignani F and Riccardi C: A rapid and simple method for measuring thymocyte apoptosis by propidium iodide staining and flow cytometry. J Immunol Methods 139: 271-279, 1991.

21. Ji YB and Yu L: N-butanol extract of Capparis spinosa L. induces apoptosis primarily through a mitochondrial pathway involving mPTP open, cytochrome c release and caspase activation. Asian Pac J Cancer Prev 15: 9153-9157, 2014.

22. Ramadevi Mani S and Lakshmi BS: G1 arrest and caspase-mediated apoptosis in HL-60 cells by dichloromethane extract of Centrosema pubescens. Am J Chin Med 38:1143-1159, 2010.

23. Raposa T and Natarajan AT: Fluorescence banding pattern of human and mouse chromosomes with a benzimidazol derivative (Hoechst 33258). Humangenetik 21: 221-226, 1974.

24. Lecellier G and Brenner C: Genomic and proteomic screening of apoptosis mitochondrial regulators for drug target discovery. Curr Med Chem 14: 875-881, 2007.

25. Im AR, Kim YH, Uddin MR, Chae S, Lee HW, Kim YS and Lee MY: Neuroprotective effects of Lycium chinense Miller against rotenone-induced neurotoxicity in PC12 cells. Am J Chin Med 41: 1343-1359, 2013.

26. Shen KH, Chen ZT and Duh PD: Cytotoxic effect of Eucalyptus citriodora resin on human hepatoma HepG2 cells. Am J Chin Med 40: 399-413, 2012.

27. Desagher S, Osen-Sand A, Nichols A, Eskes R, Montessuit S, Lauper S, Maundrell K, Antonsson B and Martinou JC: Bid-induced conformational change of $\mathrm{Bax}$ is responsible for mitochondrial cytochrome $c$ release during apoptosis. J Cell Biol 144: 891-901, 1999.

28. Cheng EH, Kirsch DG, Clem RJ, Ravi R, Kastan MB, Bedi A, Ueno K and Hardwick JM: Conversion of Bcl-2 to a Bax-like death effector by caspases. Science 278: 1966-1968, 1997.

29. Green DR and Reed JC: Mitochondria and apoptosis. Science 281: 1309-1312, 1998

30. Thornberry NA and Lazebnik Y: Caspases: Enemies within. Science 281: 1312-1316, 1998.

31. Yin XM, Oltvai ZN and Korsmeyer SJ: BH1 and BH2 domains of Bcl-2 are required for inhibition of apoptosis and heterodimerization with Bax. Nature 369: 321-323, 1994.

32. Kluck RM, Bossy-Wetzel E, Green DR and Newmeyer DD: The release of cytochrome $c$ from mitochondria: A primary site for Bcl-2 regulation of apoptosis. Science 275: 1132-1136, 1997. 